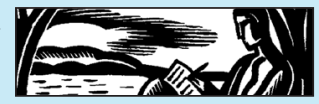

\title{
Eschewing the First Person: Post-Subjective Autobiography in Hubert Fichte and his Geschichte der Empfindlichkeit/History of Sensitivity
}

\author{
Robert Gillett
}

Queen Mary University of London

\section{ABSTRACT}

The thesis of this article is that the work of the German author Hubert Fichte, who died aged only 50 in 1986, represents an exemplary instance of post-subjective autobiography. For Fichte, writing in the aftermath of National Socialism and in the era of gay liberation, finding an alternative to the hegemonic subject position was an urgent imperative, and one to which he devoted his life's work at least from his third novel onwards. The single-mindedness with which he pursued this aim in his autobiography, and the techniques he used in the process, mean that both autobiographers and students of autobiography have a great deal to learn from him.

Keywords: Autobiography, death of the subject, German literature, Geschichte der Empfindlichkeit, History of Sensitivity, Hubert Fichte, life writing, performativity, Queer

\section{INTRODUCTION}

On the $2^{\text {nd }}$ of August 1942, a seven-year-old boy called Hubert was given a place at the catholic orphanage in Schrobenhausen, a small town situated between Augsburg and Ingolstadt, in Bavaria, Southern Germany. What is slightly surprising about this is that the boy in question was neither an orphan nor a catholic. Both his Jewish father and his anthroposophical mother were still alive, as were his Protestant maternal grandparents, who lived in Hamburg. In 1965, the prestigious Hermann Hesse Prize 
was awarded for a novel in which the eight-year-old protagonist, who, although neither an orphan nor a catholic, has been in a Catholic orphanage in Bavaria for nearly a year, is about to return, with relief, to his native Hamburg. ${ }^{1}$ Among the very many things he has learned during his time away is how vital it is not to say that his father belongs to that category of human beings who walk with splayed feet, rarely wash and are called Jews. The name of the protagonist in that novel, though, is not Hubert, but Detlev. And the orphanage is situated not in Schrobenhausen, but in a place called Scheyern. The author of this novel was born in March 1935. His father, Erwin Oberschützski, managed to escape the racial persecution of the National Socialists and went into exile in Sweden; his mother effectively brought him up as a single parent in the house of her parents in Hamburg Lokstedt. His name, like that of the child in the orphanage, was Hubert: Hubert Fichte.

Fichte's first book had been a volume of short stories, set variously in Hamburg, in the South of France and in an anthroposophical school for difficult children in Sweden. ${ }^{2}$ Each of these settings also features prominently in Fichte's biography, prompting one of the book's reviewers to characterize the book as 'Bruchstücke einer zeitgenössischen Autobiographie', 'fragments of a contemporary autobiography'. ${ }^{3}$ After his prizewinning first novel, Fichte achieved critical and commercial success in 1968 with his second one, which has as its title the name of a comparatively short-lived bar in Hamburg called Die Palette. ${ }^{4}$ In 2005 this bar was 'revisited' in a book by Jan-Frederik Bandel, Lasse Ole Hempel and Theo Janßen, who traced a number of the people Fichte had met in the bar and written about in his novel. ${ }^{5}$ The effect, as with the documents that allow researchers to trace Fichte's stay in Bavaria, is to allow a minute comparison of Fichte's novel with the reality that inspired it. ${ }^{6}$ Yet the name of the main protagonist on whom that novel is focused is neither Hubert nor Detlev, but Jäcki.

In his third novel, published in 1971 under the title Detlevs Imitationen "Grünspan", Fichte brings Detlev and Jäcki together. Jointly they do precisely what W.G. Sebald, in a series of lectures first published in book form in 1999, reproaches the Germans for not having done: explore the experience of the bombing of Hamburg in 1943. ${ }^{7}$ Detlev returns from Bavaria in time to experience the destruction at first hand; Jäcki reads up on the subject at a distance of a quarter of a century. The books Jäcki reads are real. Indeed a copy of one of them survives with marginalia in Fichte's handwriting. The club that gives the novel its name is no more fictitious than Die Palette, and the people Jäcki meets are equally real, sometimes even appearing under their own names. The same is true of some of the teachers and fellow pupils that Detlev has to deal with on a daily basis. 
This allows Gisela Ullrich to posit a similar equivalence between fiction and reality in this novel as we have established in the previous ones. ${ }^{8}$ And when in his fourth novel, Versuch über die Pubertät, Treatise on Puberty Fichte writes entirely in the first person and includes a letter addressed to a person called Hubert, this strongly suggests that the puberty being dissected is the author's own. ${ }^{9}$ It is thus gratifying, but not entirely surprising, that the novel is featured in Martina Wagner-Egelhaaf's Metzler survey of autobiography. ${ }^{10}$

Following Versuch, Fichte published no further works of narrative fiction in Germany during his lifetime. Instead he produced volumes of essays, interviews, adapted plays, radio plays and studies related to the Afro-American religions. Then, after his grotesquely early death at the age of 50 in 1986, his publisher Fischer began with the publication of a work originally planned in 19 volumes, which he had been working on, as far as we can tell, since 1974, and which he had not lived to complete. By the time this publication was declared finished in 2006, it comprised sixteen works in seventeen volumes. The title of the entire enterprise was Die Geschichte der Empfindlichkeit, The History of Sensitivity. It is generally acknowledged among Fichte scholars that the publishing history of this work is not all that it might have been. In particular, there was disagreement among the early editors as to whether the title was meant to act as a kind of sub-title for a Collected Works, or whether in fact it was to designate a work in its own right. To begin with, the former view prevailed, leading to the publication of volumes of collected essays and collected radio plays. ${ }^{11}$ After that, a second set of editors was installed, who regarded it as their duty to stick as closely as possible to the plan of the work which Fichte had drawn up on his deathbed. In one instance the decisions of the first editor made this impossible. Thus, of the volumes that were finally published, two were not part of Fichte's definitive plan for the collection, while one volume, which was, was missing. ${ }^{12}$ Subsequently, though, four have been reprinted, showing that the publisher does not really believe in the idea of a self-contained work. ${ }^{13}$ And this confusion and this uncertainty have continued to obfuscate the reception of the work - not least because, until Jan-Frederik Bandel stepped in to put matters right, noone took the trouble to examine that work as a whole. ${ }^{14}$

\section{HUBERT FICHTE AND AUTOBIOGRAPHY}

Nonetheless, the question of whether the Geschichte der Empfindlichkeit and its predecessors constitute an autobiography is hotly debated in the secondary literature. Thus Bandel, who is by far the greatest living authority 
on Hubert Fichte, is moved at one point to emphasise 'dass das, was Fichte literarisch entwirft und erzählt, eine Autobiografie weder sein kann noch will', 'what Fichte drafts and narrates in literary form neither can be, nor is meant to be, an autobiography. ${ }^{15}$ And Hartmut Böhme, who has some claim to be called the doyen of Fichte critics, likewise insists: 'Das Autobiographie-Modell der Literatur des 18. und 19. Jahrhunderts selber zum Deutungsschema einer Schriftstellerbiographie zu machen, entspricht einem Vorurteil, das [...] auf Hubert Fichte [...] nicht paßt.' ('To use the autobiography model from the literature of the $18^{\text {th }}$ and $19^{\text {th }}$ centuries itself as a paradigm for the interpretation of a writer's biography is a prejudicial procedure that does not fit Hubert Fichte.' ${ }^{16}$ Yet in one of the most recent pronouncements on the subject Christa Karpenstein-Eßbach states unequivocally: 'Alle Werke Fichtes haben autobiographischen Charakter', 'all of Fichtes works are autobiographical in character. ${ }^{17}$ And Thorsten Teichert, whose doctoral work on Fichte so impressed the author that he appointed him as one of his posthumous editors, allows himself the rhetorical question: 'Können Fichtes Texte tatsächlich als autobiographische gelesen werden?', 'Can Fichte's texts actually be read as autobiographical texts?'18

If the criterion consists in the correspondence between the facts of Fichte's own life and those described and referred to in his texts, the answer has to be yes. Almost every event recorded in the biographical sketch Fichte contributed to the volume of essays that his publisher issued for his fiftieth birthday resurfaces at some point either in the short stories, or the four novels, or in the Geschichte der Empfindlichkeit. ${ }^{19}$ Several, indeed, occur more than once. Given that a number of Fichte's passports are still to be found in his archive in Hamburg, it is relatively easy to document the precise dates of the journeys described in these texts. Comparisons with the memoirs of other individuals, with letters, reports and other documents show again and again that, while he may occasionally have put his own spin on them, he almost always retains an allegiance to the verifiable facts of his personal experience. ${ }^{20}$

If the criterion is the thoroughness with which Fichte has transposed his life into literature, then again, the answer has to be yes. Particularly telling in this regard is the fact that Fichte wrote his last novel, Explosion, almost literally on his deathbed and in it thematized precisely the process of writing a last novel while seriously ill in hospital. ${ }^{21}$ The first volume of the series begins explicitly with the question of continuity; and the answer given clearly marks this novel out as the direct sequel to the Treatise. ${ }^{22}$ And since that novel follows on seamlessly from the Imitations, which in turn begin demonstratively where the Orphanage ended, and since the Orphanage contains references to some of the protagonist's earliest memories, it 
becomes clear that Fichte's œuvre deliberately and by design covers the whole of his life from his early childhood to his impending death. Especially following the plans for the Geschichte, which clearly reveal that this was his intention, it is possible without difficulty to establish that Fichte has also accounted for virtually every one of the intervening years. ${ }^{23} \mathrm{He}$ does not do so in a linear fashion. But the premeditated completeness with which this History covers the events of its author's life makes it abundantly clear that what we are dealing with here is the 'bios' of autobiography. From this vantage point it becomes equally evident that Fichte's History constitutes a coherent whole. And that in turn gives the lie to Bandel's apodictic statement and proves that Fichte's Geschichte der Empfindlichkeit was indeed conceived as, and constitutes, an autobiography.

The form of this autobiography, however, could not be more different from that of a classic retrospective grand narrative. Even the first assumption of Lejeune's famous definition, which implicitly posits the singularity of the 'récit', clearly does not apply to this multifarious, multi-volume work. ${ }^{24}$ Indeed it is far from clear whether it makes sense to talk of 'narrative' at all - and even the term 'discours', which Lejeune allows as a kind of leaven to the autobiographical narrative, scarcely applies. ${ }^{25}$ After all, no fewer than four volumes are designated as 'Glossen', 'Glosses', and a fifth bears the curious generic label of 'Register', 'index'. ${ }^{26}$ Retrospectivity is also called into question by the sixth volume, which, with the exception of the prefatory dream narrative, is told entirely in the present tense. ${ }^{27}$ It is by no means obvious, either, that what Fichte writes is prose in the sense in which Lejeune uses the term, for the thoroughgoing use of paratacticism, the structural thematization of the blank page and therefore of blocks of text, and the massive incorporation of dialogue suggest at least equal affinities with poetry and the drama. Equally, while the title of Fichte's Geschichte der Empfindlichkeit might appear to resonate with Lejeune's postulate of an 'histoire de [1] a personnalité', the two terms are significantly different in their implications. And the fact that Fichte's whole enterprise is concerned from the very first volume with the lives of people other than its actual author runs counter to the stress Lejeune lays on the life and personal development of a single individual. For one thing, a relatively large proportion of the History of Sensitivity is devoted to formal or informal interviews. And besides, the name of the character who takes centre stage for much of that History is Jäcki and therefore not identical, as Lejeune would require, with Hubert Fichte. Except for the Glosses and the index already mentioned, the texts in which this Jäcki appears are called 'novels'. As a result, Fichte scholars are divided on the question of whether this Jäcki is to be regarded merely as an alter ego of the author, or as an autonomous fictional character. ${ }^{28}$ And Jan-Frederik 
Bandel brings the two positions together not only in a chapter entitled 'Autobiografik und Roman' but also in the term he takes over from Serge Doubrovsky: 'autofiction'. ${ }^{29}$

Of course the points of divergence between Fichte's project and canonical definitions of autobiography are no more accidental than the points of convergence touched on earlier. After all, Fichte's History is exactly contemporary with Lejeune's reflections on the genre of autobiography. ${ }^{30}$ Indeed, just like Lejeune's work on French autobiography, Fichte's reflections on his own autobiographical practice can be traced back to 1971 and Detlev's Imitations. ${ }^{31}$ In that novel Fichte brings together Detlev and Jäcki, experience and reflection on experience, and is thus able to introduce, investigate and play with the double consciousness of the autobiographer. In a laughingly apodictic assertion by an officially disqualified drag queen, the relationship between the two characters is expressed in the phrase: 'Jäcki ist eine von Detlevs Imitationen!' 'Jäcki is one of Detlev's Imitations' ${ }^{32}$ This draws attention to the title of the novel and the multifarious metaphor it contains. Thus at one level, imitation is one of the constitutive techniques of that personal development which is the substance of autobiography. Both in The Orphanage and in Detlev's Imitations it is in particular the means by which Detlev learns language. Because the language that he learns under National Socialism is so suffused with bad faith, his copying of it opens up the possibility of parody and with it at once raises and explodes one of the questions often asked of autobiography: that of authenticity. And just as postmodern theory is inclined to privilege the performative over the allegedly authentic, so it is not for nothing that, in Fichte, imitation is specifically associated with acting. Method acting provides a model of identity whereby a particular set of roles is imitated so minutely and for so long that in the end the actor is able to take them on as if from the inside. The parallels between this scenario and the social pressures operating in, say, the 1940s in Germany are as striking as they are rarely commented upon. Fichte makes the metaphor explicit and even goes one stage further. At one point his protagonist Detlev, who, like Fichte himself is a not unsuccessful child actor, is in danger of forgetting his lines. ${ }^{33}$ The crisis this leads to underlines the connection between memory and identity, which of course is constitutive of all autobiography. And by linking this connection on the one hand to the question of coming to terms with the past, 'Vergangenheitsbewältigung', and on the other to the minefield of sexuality, Fichte is able to point up the fundamental role played in all identity and hence in all autobiography by mechanisms of psycho-sexual and historico-political repression. Thus by splitting his protagonist into two and bringing the two together under the explicit auspices of imitation, Fichte is both exposing the mechanisms 
of autobiographical writing and the sleight of hand they imply, while at the same time radically calling into question the notion of the unitary subject that they so often presuppose.

\section{HUBERT FICHTE AND THE DEATH OF THE SUBJECT}

Bombed to bits by the incendiaries of the Anglo-Americans, rendered morally untenable by the association with National Socialism, forced into a ghetto of inauthentic assimilation by the totalitarianism of the strongarmed majority, and thoroughly discredited by the obsessive revelations of psychoanalysis, the idea of the subject as experienced and explored in Fichte's third novel is a site of thoroughgoing contestation; and it is this, rather than any kind of privileged truth-telling, that constitutes the novel as an act of autobiography. At several points, indeed, the process is made absolutely explicit. Thus when Detlev is trying to remember himself, the text that occurs to him is the opening of the novel by Fichte in which he put in his first, unalterable appearance. ${ }^{34}$ And in a passage that follows on immediately from Detlev's reflections on what he might become in a future made literally unthinkable by the destruction of the war, the issue of the autobiographical subject is again transposed to the level of textuality:

Ich.

Wer ich?

Ich?

Du?

Sie?

Wenn ich 'ich' schreibe, denken Sie an sich oder an mich?

Jäcki?

Detlev?

- Waren Sie nun persönlich auch im Waisenhaus?

- Aber Jäcki und Detlev sind doch zwei Figuren aus Fleisch und Blut?

Gestalten aus Fleisch und Blut. Leichen aus Fleisch und Blut.

- Finden Sie nicht auch, daß Jäcki und Detlev viele gemeinsame Züge haben?

Ich?

Sie und ich und Detlev und Jäcki und Jäckis Ich und Detlevs Ich und mein Ich und Ihr Ich..$^{35}$

$-\mathrm{I}$.

Who I?

I?

You?

You? 
When I write 'I', do you think of yourself or of me?

Jäcki?

Detlev?

- Now were you personally in the orphanage too?

- But Jäcki and Detlev are two figures of flesh and blood?

Figures of flesh and blood. Corpses of flesh and blood.

- Don't you think, too, that Jäcki and Detlev have many features in common?

I?

You and I and Detlev and Jäcki and Jäcki’s I and Detlev's I and my I and your I. ${ }^{36}$

Crucially, what this passage does is to ask what it means to posit a subject in a text. It does so in a multiply dialogical situation that goes way beyond matters of narrative perspective. Thus the 'I' of the person writing is here only one of four possible referents. The untranslatable pronoun of intimate address carries with it the suggestion of a ventriloquist monologue, since that is what people use when they talk to themselves. The invocation of the reader raises the issue of the voicing of the first person. And the chiasmus of the last line sets up a mirroring effect in which a person and that person's 'I' become disidentical. The whole process is associated explicitly with precisely the sort of questions regularly asked by those seeking to delimit the genre of autobiography - about the status of the first person, about the actual experience of the author, about authenticity and realism. By disrupting this discourse with a reference to corpses, Fichte suddenly removes the question of the subject from the seemingly abstract and harmless realm of literary criticism to the genuinely dangerous sphere of demagogy and politics. The effect of that is to imbue the question about the similarity between the half-Jew Detlev and the homosexual Jäcki with its own subliminal menace, which also rubs off on the author and reminds us that behind his refusal to adjudicate between the two protagonists is precisely a lived awareness of their shared oppression.

As a homosexual, of course, Fichte was faced with the doubly inauthentic choice of imitating the attributes of alleged straightness or mimicking the femininity ascribed to him by an irrational but inescapable heterocentric logic. And so it is that in the passage that immediately follows he begins his self-portrait of the author as autobiographer with the overdetermined application of make-up:

Ich vergrößere meine Augen mit Belladonna, verzeichne meine Brauen und die Haut unter den Wimpern zum Tigerlook. Über Mund und Nase ziehe ich bunte fettige Querstreifen wie auf dem Reklamefoto von »etwas Neues bei Christian Dior..", setze mir eine blonde Perücke auf und ziehe den 
Paillettenhosenanzug des lesbisch gewordenen operierten Transvestiten an, stülpe den Federhelm auf mit den Papphörnern, binde mir Flamingoflügel um, behänge meinen Gürtel mit Entenfüßen und Korallenästen, werfe den Schleier über und besteige das perlenbestickte Schaukelpferd des Dichters und warte, daß die Hähne über mir geschlachtet werden und man die Daunen mit dem Blut an meinem Schleier festklebt und imitiere Detlev, der die Iphigenie auf Tauris imitiert. ${ }^{37}$

I enlarge my eyes with belladonna, draw over my brows and the skin under the lashes for a tiger look. I draw bright greasy diagonal stripes across mouth and nose, as in the advertisement for 'something new from Christian Dior...', place a blond wig on my head and put on the sequined trouser suit of the transvestite who's had an operation and become a lesbian, clap the feather helmet with the cardboard horns on top of it, tie on flamingo wings, hang ducks' feet and twigs of coral from my belt, drape the veil over myself and mount the poet's pearl embroidered rocking horse and wait for the hens to be slaughtered over me and the feathers to be stuck firmly to my veil with the blood and imitate Detlev, who is imitating Iphigenia on Tauris. ${ }^{38}$

It is hard to imagine a more complete disavowal of the discourse of authenticity than this. After all, the passage begins with a deliberate gesture in which the narrating subject self-consciously exaggerates his own appearance. This underlines the fact that all autobiographies entail an element of over-determinate mimicry. Like actors who have to distort themselves in order to look natural in the artificial atmosphere of stage lighting, autobiographers have to adopt an inauthentic persona in order to achieve the illusion of authenticity in the counterfeit world of literature. In so doing they are also playing the sort of complicated game with performance and expectation that characterizes the mode of being known as camp. In both it is the very excess of the performance, together with the adoption of a canon of style which is none the less rigorous for being counter-cultural, that turn out to be the paradoxical precondition for acceptance. By camping it up at just that moment where his autobiographer interrogates the subject, then, Fichte effectively demonstrates that all identity is a performance put on within certain ideological constraints. By invoking the bloodbaths of the syncretic religions in this context, Fichte is acknowledging both those constraints and a possible attempt to elude them. For the process of initiation, which is of course another staple of autobiography, here occurs in a context predicated on slavery, and is designed to induce a trance and hence transcendence. By the same token, it makes perfect sense that what Fichte's autobiographer is doing in our text is elaborately assuming drag. With it, the 'ich' of autobiography is accomplishing a gesture of what Judith Butler has called 'gender 
insubordination' ${ }^{39}$ And for Fichte as for Butler, one of the first victims of that insubordination is the ideological fiction of the subject.

That is precisely the theme of Fichte's fourth novel, Versuch über die Pubertät, Treatise on Puberty. There the method-acting model of identity from Detlev's Imitations is complemented and in part overturned by a rival conception whereby authenticity effects are indeed achieved by analysis and deliberate exaggeration. If in Detlev Fichte had used a pair of protagonists in order insistently to ask about the identity of the I, so in On Puberty he uses a pair of other puberties to shed light on his own and imposes on his 'I' the enjoinder 'call yourself a novel'. ${ }^{40}$ The text in which he does this occupies a structurally equivalent position within the economy of the novel as the text from Detlev's Imitations does there. It begins with a periphrastic refusal of the first person: 'Ich, sage ich, würde nie ein Buch in der ersten Person schreiben', 'I say I would never write a book in the first person'. ${ }^{41}$ And the explanation features not the 'poet's pearl-embroidered rocking horse' but something altogether more prosaic: 'Im Ich sitzt man im Drehstuhl und sieht auf eine überwundene Zeit', 'With the I you find yourself in a swivelling chair looking back on spent time.' In other words, adopting the position of the retrospective subject, precisely because it precludes the possibility of imitation, ventriloquism, trance and transcendence, entails sacrificing the possible magic of the writing process to the unreconstructed rationalism of the Enlightenment: 'Ich: aufgeklärt, unmagisch, verlogen', 'I, enlightened, unmagical, spurious. ${ }^{.2}$ In a novel which draws heavily on the syncretic religions and is thus acutely aware of the wholesale destruction wrought by the hegemonic unmagic of Western colonialism, these three adjectives bear an enormous weight of condemnation. Yet at the same time the entire novel figures puberty as precisely the ineluctable transition to that kind of complicit subject-position. That is why the novel is written in the first person in the first place. But it is also why Fichte is constantly looking for ways to attenuate the I and turn it into a novel. This he does not only by invoking the syncretic religions and puberties other than his own, but also by arranging the personnel of the book in groups of comparable age, so that one sexagenarian invites comparison with another, one forty-year-old with another and so on; and by resorting to collage and montage, the 'versus rapportati' and the 'contenu mental'. Extreme effects of mutual empathy are achieved when the narrator uses his own experiences of danger and terror under the Papa Doc regime on Haiti in order to explore and understand the factors that led his pederastic lover to attempt suicide ${ }^{43}$ Where in the Imitations Fichte had used the double protagonist in order to contrast personal experience with objective investigation, while lambasting both sentimental exaggeration and unfeeling scientificity, in his Treatise he dissects dissection itself 
and insists that truth is to be found rather in a knowing multiplication of approximations than in a totalitarian attempt to strip away that which is not germane. Accordingly the whole text works with a series of mirrors and equivalences, which have the effect of refracting identity and reconstituting the voice of the autobiographer as a programmatic polyphony.

\section{THE HISTORY OF SENSITIVITY AS POST-SUBJECTIVE} AUTOBIOGRAPHY

This is a process which is continued and amplified in the great autobiographical project which Fichte began writing at about the time of the Treatise and which demonstrably takes over where the Treatise ended. Like the Treatise, the Geschichte begins - not accidentally - with an act of dissection: 'Er zerschnitt ihre Fotos' - 'He cut up her photos. ${ }^{44}$ The indeterminacy of the pronouns here, together with the resonant metaphor of destructive analysis, mark this opening out as a primal scene which defers the continuation of the narrative in order to recount and reflect on the parameters of its possibility: the subject and object of narration, the gender and profession of the intended audience, differently cathected reproductions of reality and the tendentious violence done to these. By the same token, the deliberate situation of the act of story telling in the woman's bedroom in the 'hotel garni' explicitly underlines the sexual dimension of this - and all - autobiography. And the staging of the autobiographical narrative as a dialogue in which the interlocutor can question and interrupt, but also reassure and affirm, has the effect of attenuating the sovereignty of the narrating subject. This sovereignty is then completely undermined when the interview that is a continuation of and a metonymy for the sex between the gay protagonist and the woman who will become his partner is in danger of succumbing to self-doubt and only rescued by the swift intervention of the latter. ${ }^{45}$ And as in the Treatise, of course, the inclusion of another life story both slackens and enriches the autobiographical narrative by inviting comparisons and changing the perspective.

The last volume of the History also refers explicitly to the Treatise by updating an interview included there and taking up again the rhetorical device of the 'versus rapportati' ${ }^{46}$ This, though, is only one of very many intertextual associations promised by the title and delivered by the book itself. ${ }^{47}$ The allusional nature of this text, which is acutely aware of detumescence and death, formally disavows the teleology of an 'histoire' or a 'development' by revisiting and relativizing, measuring change, comparing and recanting. And just as Hotel Garni had begun with an indeterminate pronoun which later resolves into a Jäcki who says I, so Hamburg 
Hauptbahnhof ends with an indeterminate third person pronoun taking the place of a Jäcki who had been tempted to rescue the ego and the superego and seeking by means of a novel to repudiate Fichte's first novel, his eighth, and the whole Geschichte der Empindlichkeit. ${ }^{48}$

In between Fichte's History dramatizes completeness and fragmentation, formal complexity and aleatoric juxtaposition. The third volume is explicitly marked as a fragment in at least three different ways $;{ }^{49}$ another is qualified on the flyleaf as a first draft; ${ }^{50}$ others again are not even that far developed ${ }^{51}$ Yet an encounter with a Moslem country is recounted in a highly organized form that reflects on - and reverses - the Koran. ${ }^{52}$ And a novel entitled Forschungsbericht, Research Report takes the obligatory form of the fieldwork diary and reworks it with the help of Herodotus, Henry James and Agatha Christie so that in the end it dissolves into a self-perpetuating fiction. ${ }^{53}$ As in Goethe's paradigmatic precedent, Fichte places his own literary ouvre at the heart of his enterprise by using the autobiographical frame to shed light on it. One text for example can occur in different contexts, drawing attention to different aspects of its contents and the life that produced it. Or disparate literary or journalistic works are gathered together in approximately chronological order, explicitly constituting a gloss on a particular period of the writer's life. ${ }^{54}$ Or the first commission of a travel feature by a radio producer is recorded in all its circumstantial detail and followed by the feature itself. ${ }^{55}$ And even beyond that, the relative significance accorded to particular works of art within an euvre is reflected in an editorial practice which places in an appendix texts whose place in the body of the work is not certain. ${ }^{56}$

It is noticeable too that within the History as a whole Fichte maintains the same rhythm of narrative and analysis which he had previously observed in individual novels. Not only do individual works begin with resonant poetological reflections, ${ }^{57}$ but the works of metanarrative significance alternate with the carefully crafted novels. And just as the narratives tell the story of Fichte's life to the bitter end, so the metanarratives continue the interrogation of the genre of autobiography down to the tiniest textual and intertextual detail. There is a moment in Alte Welt, Old World, for example, where Fichte juxtaposes a text allegedly taken from a diary with an allegedly literary treatment of the same material. ${ }^{58}$ The effect is to force a critical reassessment of the attributes we unthinkingly attribute to the two genres - spontaneity and careful composition, honesty and diplomacy, the private and the public. Woven into the whole enterprise from the second volume onwards is an explicit demonstration of and discussion about the tricky category of gossip, which cannot but reflect back on its author both as the perpetrator of tittle-tattle, and as its victim. ${ }^{59}$ The volume Psyche indeed, which is ostensibly concerned with 
the treatment of the mentally ill in Sub-Saharan Africa, contains both a theoretical excursus on the nature of gossip and surprising reflections on the subject and its constitution. ${ }^{60}$

The two are of course intimately linked, as Brigitte Weingart has shown and Fichte impressively demonstrates.$^{61}$ Similarly, the programmatic alternation of complete and less completed works is itself a commentary on the literary and biographical impossibility of ever finishing an autobiography - a commentary which is repeated diegetically in Explosion. ${ }^{62}$ And the mise en abyme to which Fichte subjects the autobiographical genre of the diary in Forschungsbericht, Research Report has the necessary corollary of ironizing both the subject and his writing. In other words, what Fichte is deliberately trying to do in his self-conscious manipulation of the genre of autobiography is precisely to dislodge the discredited ' $I$ ' from its position as privileged subject. That is why the complex also includes important contributions by very many other people, often in the form of interviews, or snatches of dialogue, or letters. Where one might expect the declarative gesture of coming out, for example, we are presented instead with a programmatic exploration of a relationship with a woman, who has a crucial role as addressee and moral instance, and who is briefly but repeatedly given a voice of her own. Instead of passively experiencing the observational and hence judgemental mode of travel writing, we get involved in adventures, which as often as not end up in failure, listen in on interviews, and are encouraged to compare different points of view. Where other literary autobiographies present authorship as a triumphant teleology, Fichte dwells on issues of ideology, indulges in painstakingly innocent gossip and compares writing to prostitution. And throughout he explicitly counters the hegemonic uncuriosity of Western colonialism with an avowedly sexual interest in the affairs of black men. In all these respects he is concerned to overturn the unreconstructed solipsism of the standard Western autobiographical subject and to replace it with something altogether less monologic and hegemonic. ${ }^{63}$

The word Fichte uses to designate this alternative is 'Empfindlichkeit', 'Sensitivity'. What is at stake is both a quality in photographic paper and hence a function of the recording of reality, and a rawness of the nerves, a prickliness; both a physiological mechanism for feeling individual pain and pleasure and an emotional receptivity to the needs and advances of others; both a historically specific cast of feeling and a particular quality which can serve as a criterion for judgement. To write a Geschichte der Empfindlichkeit, then, entails picking up as many nuances as possible of historical and biographical events while refusing easy and conventional attitudes and remaining intensely self-aware and self-critical. It involves an uncompromising openness not only to physical sensation, but also the 
lives, views and perspectives of others. It will combine a minute examination of mentalities and the forces that shaped them with the moral probity and courage to condemn tergiversation. But above all it is to put the self and the life it leads at the service of a kind of writing that is also a bearing witness. That of course is what is meant by life writing, and why life writing is important. In his History Fichte conjugates the concept through (almost) all its generic forms and ideological implications. In the process, he never ceases to interrogate the subject and its relation to performance on the one hand and text on the other. He never posits a safe self and the voice he speaks in is very often shrill with ventriloquism. And as with camp, the essence of that ventriloquism has to do with an imitative repudiation of those structures of thought whereby the unchecked ego of the subject is apt to become totalitarian.

Now the threats to the subject that Fichte posits and records are neither abstract nor theoretical, but harrowingly specific: the concentration camp, indiscriminate fire-bombing, terror and torture, lobotomy and castration. As his Detlev discovered in the orphanage and under National Socialism, the mental processes that lead human beings to commit these atrocities are not exceptional; neither have they been superseded. They are endemic in all those forms of language in which the self posits its own superiority over others. The number of autobiographies that owe their existence to precisely this assumption is legion. Fichte's alternative redefines the parameters of the genre ethically and aesthetically, making many other examples literally unreadable. In that sense, to say, as Bandel and Böhme do, that what Fichte wrote was the polar opposite of what is usually meant by autobiography suddenly seems like an understatement. What Fichte achieved in his short stories, his novels and his History of Sensitivity was not an autobiography as we know it. It was something altogether different, extraordinary and exemplary: a model of post-subjective life writing.

\section{BIBLIOGRAPHY}

Bandel, Jan-Frederik, ed. Tage des Lesens. Hubert Fichtes Geschichte der Empfindlichkeit. Aachen: Rimbaud, 2006.

Bandel, Jan-Frederik. Nachwörter. Zum poetischen Verfahren Hubert Fichtes. Aachen: Rimbaud, 2008.

Bandel, Jan-Frederik, Lasse Ole Hempel, and Theo Janßen. Palette Revisited. Eine Kneipe und ein Roman. Hamburg: Nautilus, 2005.

Böhme, Hartmut. Hubert Fichte. Riten des Autors und Leben der Literatur. Stuttgart: Metzler, 1992.

Butler, Judith. "Imitation and Gender Insubordination". Ed. Fuss, D. Inside/Out. Lesbian Theories/ Gay Theories. New York and London: Routledge, 1991. 13-31. 
Fichte, Hubert. Der Aufbruch nach Turku. Erzählungen. Hamburg: Hoffmann \& Campe, 1963. Fichte, Hubert. Das Waisenhaus. Reinbek: Rowohlt, 1965.

Fichte, Hubert. Die Palette. Reinbek: Rowohlt, 1968.

Fichte, Hubert. Detlevs Imitationen „Grünspan “. Reinbek: Rowohlt, 1971.

Fichte, Hubert. Versuch über die Pubertät. Hamburg: Hoffmann \& Campe, 1974.

Fichte, Hubert. "Biographische Skizze." Ed. Beckermann, Thomas. Hubert Fichte. Materialien zu Leben und Werk. Frankfurt am Main: Fischer, 1985. 317-322.

Fichte, Hubert. Hotel Garni. Die Geschichte der Empfindlichkeit, vol 1. Frankfurt am Main: Fischer, 1987.

Fichte, Hubert. Homosexualität und Literatur 1. Polemiken. Die Geschichte der Empfindlichkeit, Paralipomena 1. Frankfurt am Main: Fischer, 1987.

Fichte, Hubert. Homosexualität und Literatur 2. Polemiken. Die Geschichte der Empfindlichkeit, Paralipomena 1. Frankfurt am Main: Fischer, 1988.

Fichte, Hubert. Schulfunk. Hörspiele. Die Geschichte der Empfindlichkeit, Paralipomena 4. Frankfurt am Main: Fischer, 1988.

Fichte, Hubert. Der kleine Hauptbahnhof oder Lob des Strichs. Die Geschichte der Empfindlichkeit, vol. 2. Frankfurt am Main: Fischer, 1988.

Fichte, Hubert. Das Haus der Mina in São Luiz de Maranhão. Materialien zum Studium des religiösen Verhaltens. Zusammen mit Sergio Ferretti. Die Geschichte der Empfindlichkeit, Paralipomena 2. Frankfurt am Main: Fischer, 1989.

Fichte, Hubert. Der Platz der Gehenkten. Die Geschichte der Empfindlichkeit, vol. 6. Frankfurt am Main: Fischer, 1989.

Fichte, Hubert. Forschungsbericht. Roman. Die Geschichte der Empfindlichkeit, vol. 15. Frankfurt am Main: Fischer, 1989.

Fichte, Hubert. The Orphanage. Trans. Martin Chalmers. London: Serpent's Tail, 1990.

Fichte, Hubert. Psyche. Glossen. Die Geschichte der Empfindlichkeit. Frankfurt am Main: Fischer, 1990.

Fichte, Hubert. Die schwarze Stadt. Glossen. Die Geschichte der Empfindlichkeit. Frankfurt am Main: Fischer, 1991.

Fichte, Hubert. Lils Book. Die Geschichte der Empfindlichkeit, Paraleipomena. Frankfurt am Main: Fischer, 1991.

Fichte, Hubert. Detlev's Imitations. Trans. Martin Chalmers. London: Serpent's Tail, 1992.

Fichte, Hubert. Alte Welt. Glossen. Die Geschichte der Empfindlichkeit, vol 5. Frankfurt am Main: Fischer, 1992.

Fichte, Hubert. Explosion. Roman der Ethnologie. Die Geschichte der Empfindlichkeit, vol. 7. Frankfurt am Main: Fischer, 1993.

Fichte, Hubert. Hamburg Hauptbahnhof. Register. Die Geschichte der Empfindlichkeit. Frankfurt am Main: Fischer, 1994.

Fichte, Hubert. Detlevs Imitationen „Grünspan“, Frankfurt am Main: Fischer Taschenbuch, 2005.

Fichte, Hubert. Versuch über die Pubertät, Frankfurt am Main: Fischer Taschenbuch, 2005.

Fichte, Hubert. Die Zweite Schuld. Glossen. Die Geschichte der Empfindlichkeit, vol. 3. Frankfurt am Main: Fischer, 2006.

Gillett, Robert. "Huberts Imitationen. Intertextualität in und um Grünspan." Ed. Böhme, Hartmut \& Tiling, Nikolaus. Medium und Maske. Die Literatur Hubert Fichtes zwischen den Kulturen. Stuttgart: M\&P, 1995. S. 303-333.

Gillett, Robert. "Späte Entlarvung oder üble Nachrede? Überlegungen zu einem noch nicht verjährten Plagiatsvorwurf, Hubert Fichte und Heimito von Doderer betreffend". Ed. Claude Conter, Justitiabilität und Rechtmäßigkeit. Verrechtlichungsprozesse von Literatur und Film in der Moderne. Amsterdam \& New York: Rodopi, 2010. 85-95.

Gillett, Robert. "Aber eines lügt er nicht: Echtheit". Perspektiven auf Hubert Fichte. Hamburg: Textem, 2013. 
Karpenstein-Eßbach, Christa. "Hubert Fichte und die Montagne de Lure." Cahiers d'Études Germaniques 60 (2011): 321-331.

Koller, Reinhold. "Schriftsteller Hubert Fichte in Schrobenhausen. Fakten und Daten zum Aufenthalt des Waisenhaus-Autors 1941-1943.” Schrobenhausener Zeitung, Heimat-Blätter 5 (1991): H. 1, 1-2.

Krolow, Karl. "Bruchstücke einer zeitgenössischen Autobiographie." Süddeutsche Zeitung 4.12 (1963).

Linck, Dirck. “'Die Reinheit fand Jäcki furchtbar.' Über die Nobilitierung der Vermischung bei Hubert Fichte." In: FORUM Homosexualität und Literatur 47 (2006): 49-74.

Sebald, W.G. Luftkrieg und Literatur. Munich and Vienna: Hanser, 1999.

Sebald, W.G. On the Natural History of Destruction. Trans. Anthea Bell. London: Notting Hill Editions, 2012.

Teichert, Thorsten. „Herzschlag aussen“. Die poetische Konstruktion des Fremden und des Eigenen im Werk Hubert Fichtes. Frankfurt am Main: Fischer, 1987.

Ullrich, Gisela. Identität und Rolle. Probleme des Erzählens bei Johnson, Walser, Frisch und Fichte. Stuttgart: Klett, 1977.

Wagner-Egelhaaf, Martina. Autobiographie. Stuttgart: Metzler, 2000.

Weingart, Brigitte. Ansteckende Wörter. Repräsentationen von AIDS. Frankfurt am Main: Suhrkamp, 2002.

\section{ABOUT THE AUTHOR}

Robert Gillett is Reader in German and comparative cultural studies at Queen Mary University of London. In addition to more than twenty items on Hubert Fichte, including a bibliography and the monograph 'Aber eines lügt er Nicht: Echtheit' (2013), he has edited books and special issues on Brecht, Johann Peter Hebel, Uwe Johnson, and Queer, and written a number of articles on contemporary German-language poetry. He is currently engaged, with Astrid Köhler, in editing the complete works of the East German poet Adolf Endler.

\section{NOTES}

1 Fichte, Hubert, Das Waisenhaus. Reinbek, Rowohlt 1965. Fichte, Hubert, The Orphanage. Translated by Martin Chalmers. London, Serpent's Tail 1990.

2 Fichte, Hubert, Der Aufbruch nach Turku. Erzählungen. Hamburg, Hoffmann \& Campe 1963.

3 Krolow, Karl, 'Bruchstücke einer zeitgenössischen Autobiographie', Süddeutsche Zeitung 4.12.1963.

4 Fichte, Hubert, Die Palette. Reinbek, Rowohlt 1968.

5 Bandel, Jan-Frederik, Lasse Ole Hempel \& Theo Janßen, Palette Revisited. Eine Kneipe und ein Roman. Hamburg, Nautilus 2005.

6 Cf. Koller, Reinhold, 'Schriftsteller Hubert Fichte in Schrobenhausen. Fakten und Daten zum Aufenthalt des Waisenhaus-Autors 1941-1943', Schrobenhausener Zeitung, HeimatBlätter 5 (1991), H. 1, pp. 1-2. 
7 Fichte, Hubert, Detlevs Imitationen „Grünspan“. Reinbek, Rowohlt 1971. Sebald, W.G., Luftkrieg und Literatur. Munich and Vienna, Hanser 1999, pp. 70-72, 93-94. Fichte, Hubert, Detlev's Imitations. Translated by Martin Chalmers. London, Serpent's Tail 1992. Sebald, W.G., On the Natural History of Destruction. Translated by Anthea Bell. London, Notting Hill Editions 2012, pp. 58-60.

8 Ullrich, Gisela, Identität und Rolle. Probleme des Erzählens bei Johnson, Walser, Frisch und Fichte. Stuttgart, Klett 1977, p. 115.

9 Fichte, Hubert, Versuch über die Pubertät. Hamburg, Hoffmann \& Campe 1974.

10 Wagner-Egelhaaf, Martina, Autobiographie. Stuttgart, Metzler 2000, p. 191.

11 Fichte, Hubert, Homosexualität und Literatur. Die Geschichte der Empfindlichkeit, Paralipomena 1. 2 vols, Frankfurt am Main, Fischer 1987 \& 1988. Fichte, Hubert, Schulfunk. Hörspiele. Die Geschichte der Empfindlichkeit, Paralipomena 4. Frankfurt am Main, Fischer 1988.

12 On this, see Bandel, Jan-Frederik, ed., Tage des Lesens. Hubert Fichtes Geschichte der Empfindlichkeit. Aachen, Rimbaud 2006.

13 Fichte, Hubert, Eine Glückliche Liebe. Die Geschichte der Empfindlichkeit vol. 4. Frankfurt am Main, Fischer 2005; Fichte, Hubert, Forschungsbericht. Roman. Die Geschichte der Empfindlichkeit, vol 15. Frankfurt am Main, Fischer 2005; Fichte, Hubert, Platz der Gehenkten. Die Geschichte der Empfindlichkeit, vol. 6. Frankfurt am Main, Fischer 2006; Fichte, Hubert, Explosion. Die Geschichte der Empflindlichkeit, vol 7. Frankfurt am Main, Fischer 2006.

14 Bandel, ed., Tage des Lesens.

15 Bandel, Jan-Frederik, Nachwörter. Zum poetischen Verfahren Hubert Fichtes. Aachen, Rimbaud 2008, p. 30. All translations, unless otherwise stated, are by the author.

16 Böhme, Hartmut, Hubert Fichte. Riten des Autors und Leben der Literatur. Stuttgart, Metzler 1992, p. 23.

17 Karpenstein-Eßbach, Christa, 'Hubert Fichte und die Montagne de Lure'. Cahiers d'Études Germaniques 60, 2011, pp. 321-331, p. 321.

18 Teichert, Thorsten, „Herzschlag aussen“. Die poetische Konstruktion des Fremden und des Eigenen im Werk Hubert Fichtes. Frankfurt am Main, Fischer 1987, p. 49.

19 Fichte, Hubert, 'Biographische Skizze'. In: Beckermann, Thomas, ed., Hubert Fichte. Materialien zu Leben und Werk. Frankfurt am Main, Fischer 1985, pp. 317-322.

20 For one particular instance of this, see Gillett, Robert, 'Späte Entlarvung oder üble Nachrede? Überlegungen zu einem noch nicht verjährten Plagiatsvorwurf, Hubert Fichte und Heimito von Doderer betreffend.' In: Conter Claude, ed., Justitiabilität und Rechtmäßigkeit. Verrechtlichungsprozesse von Literatur und Film in der Moderne. Amsterdam \& New York, Rodopi 2010, pp. 85-95.

21 Fichte, Explosion, pp. 276-278.

22 Fichte, Hubert, Hotel Garni. Die Geschichte der Empfindlichkeit, vol 1. Frankfurt am Main, Fischer 1987, p. 8.

23 See Gillett, Robert, "Aber eines lügt er nicht: Echtheit". Perspektiven auf Hubert Fichte. Hamburg, Textem 2013, pp. 62-75.

24 Since in what follows I shall be referring point by point to this definition, it seems indispensable to quote it in full, even though it is likely to be very well known to all readers of this journal: 'Récit retrospectif en prose qu'une personne réelle fait de sa propre existence, lorsqu'elle met l'accent sur sa vie individuelle, en particulier sur l'histoire de sa personnalité.' (Lejeune, Philippe, Le pacte autobiobraphique. Paris, Éditions du Seuil 1975, p. 14). The translation quoted by Linda Anderson adds an indefinite article which underlines the point being made here: 'A retrospective prose narrative produced by a real person concerning his own existence, focusing on his individual life, in particular on the development of his personality.' Anderson, Linda, Autobiography. London and New York, Routledge 2001, p. 2.

25 Lejeune, Pacte autobiographique, p. 14. 
26 Fichte, Hubert, Psyche. Glossen. Die Geschichte der Empfindlichkeit. Frankfurt am Main, Fischer 1990; id, Alte Welt. Glossen. Die Geschichte der Empfindlichkeit. Frankfurt am Main, Fischer 1992; id, Die schwarze Stadt. Glossen. Die Geschichte der Empfindlichkeit. Frankfurt am Main, Fischer 1990; id., Die zweite Schuld. Glossen. Die Geschichte der Empfindlichkeit, vol 3, Frankfurt am Main, Fischer 2006; id, Hamburg Hauptbahnhof. Register. Die Geschichte der Empfindlichkeit. Frankfurt am Main, Fischer 1994.

27 Fichte, Der Platz der Gehenkten.

28 See Bandel, Nachwörter, S. 21; Böhme, Hubert Fichte, S. 327.

29 Bandel, Nachwörter, S. 26-30, S. 45-51.

30 See the bibliography appended to Lejeune, Philippe, Les Brouillons de soi. Paris, Éditions du Seuil 1998, p. 6.

31 Lejeune, Philippe, L'autobiographie en France. Paris, Armand Colin 1971.

32 Fichte, Hubert, Detlevs Imitationen „Grünspan“. Frankfurt am Main, Fischer 2005.

33 Fichte, Detlevs Imitationen „Grünspan“ (2005), pp. 170-171, Fichte, Detlev's Imitations, pp. 179-180.

34 Ibid.

35 Fichte, Detlevs Imitationen „Grünspan“ (2005), p. 69.

36 Fichte, Detlev's Imitations, pp. 71-2.

37 Fichte, Detlevs Imitationen „Grünspan“ (2005), pp. 69-70.

38 Fichte, Detlev's Imitations, p. 72.

39 Butler, Judith, 'Imitation and Gender Insubordination'. In Fuss, D., ed., Inside/Out. Lesbian Theories/ Gay Theories. New York and London, Routledge 1991, pp. 13-31.

40 Fichte, Hubert, Versuch über die Pubertät. Frankfurt am Main, Fischer 2005, pp. 123-139; pp. 255-277; p. 36.

41 Fichte, Versuch über die Pubertät (2005), p. 36,

42 Fichte, Versuch über die Pubertät (2005), p. 37.

43 Fichte, Versuch über die Pubertät (2005), pp. 162-182.

44 Fichte, Hotel Garni, p. 7.

45 Fichte, Hotel Garni, pp. 160-61.

46 Fichte, Hamburg Hauptbahnhof, pp. 183-218, pp. 25-27, pp. 219-221; Fichte, Versuch über die Pubertät, (2005) pp. 123-139, pp. 47-49.

47 On this, see Gillett, Aber eines lügt er nicht, pp. 75-76.

48 Fichte, Hamburg Hauptbahnhof, p. 284.

49 Fichte, Die zweite Schuld.

50 Fichte, Explosion.

51 Fichte, Alte Welt; Fichte, Die schwarze Stadt.

52 Fichte, Der Platz der Gehenkten.

53 Fichte, Forschungsbericht.

54 Fichte, Alte Welt; Fichte, Die schwarze Stadt. Given that these two texts refer respectively to the old world of Europe and the new one of New York, it is not accidental that they should be similar in this respect.

55 Fichte, Alte Welt, pp. 1-54.

56 Fichte, Alte Welt, pp. 614ff: 'Die folgenden journalistischen Arbeiten Hubert Fichtes aus den Jahren 1962 und 1963 lagen vor dem Titelblatt der Alten Welt. Da aber innerhalb des Werkes seine journalistische Tätigkeit der Jahre 1966 bis 1969 thematisiert wird und Fichte den genauen Ort dieser Arbeiten nicht bestimmt hat, erscheinen sie an dieser Stelle.'

57 On this, see Gillett, Aber eines lügt er nicht, pp. 92-93.

58 Fichte, Alte Welt, pp. 293 \& 323.

59 Fichte, Psyche, p. 17 and p. 507. Cf. Fichte, Hubert, Der kleine Hauptbahnhof oder Lob des Strichs. Die Geschichte der Empfindlichkeit, vol. 2. Frankfurt am Main, Fischer 1988, esp. p. 43 and Fichte, Die zweite Schuld. 
60 Fichte, Psyche, pp. 16-19, pp. 506-8, pp. 10-14, p. 353.

61 Weingart, Brigitte, Ansteckende Wörter. Repräsentationen von AIDS. Frankfurt am Main, Suhrkamp 2002, pp. 156-174, pp. 177-178.

62 See above, note 21.

63 On this, see Linck, Dirck, “'Die Reinheit fand Jäcki furchtbar.” Über die Nobilitierung der Vermischung bei Hubert Fichte.' In: FORUM Homosexualität und Literatur 47 (2006), pp. 49-74 and cf. Gillett, Robert, 'Huberts Imitationen. Intertextualität in und um Grünspan.' In: Böhme, Hartmut \& Tiling, Nikolaus, eds., Medium und Maske. Die Literatur Hubert Fichtes zwischen den Kulturen. Stuttgart, M\&P 1995, S. 303-333. 